\section{Post-war Medical Relief}

IN a timely pamphlet (Post-War Problems Medical Relief in Europe. The Royal Institute of International Affairs, 1942. Pp. 67. 2s. net.), Dr. M. D. Mackenzie emphasizes the importance of organizing before the end of the War a central co-ordinating administrative machine composed at first of delegates of the allied countries and later of representatives of occupied countries as well. $\mathrm{He}$ suggests that the Health Organisation of the League of Nations, which still functions, should be used and should be joined by international voluntary organizations (International Red Cross, Society of Friends, ete.), British and American voluntary organizations for relief in Europe and the national voluntary organization in each of the countries to which relief is being given. In addition to food and elothing, medical relief material of all kinds will be wanted, including vaccine against smallpox and onteric fever, disinfectants, quinine and other important drugs, as well as reestablishment of the milk supply. The specific diseases which will need attention are malnutrition including tuberculosis, typhus fever, malaria and other infectious diseases as well as cardiac and digestive disorders.

\section{Smallpox in the United States}

According to an annotation in the June issue of the Statistical Bulletin, the organ of the Metropolitan Life Assurance Company of New York, a remarkably low record for smallpox was established for 1941 in the United States, only 1,432 cases having been reported in the whole country during that year, or scarcely more than half the number notified in 1940 $(2,795)$. In Canada also the incidence of smallpox was very low, only 26 cases having been reported, all but one of which occurred in the single province of Saskatchewan. As in previous years, the type of the disease in the United States was mild, and it is probable that not more than ten deaths occurred. There is good reason to believe that the present decline is real, and that the disease will be eradicated in the next decade. During the past twenty-one years, nearly half a million cases of smallpox have been reported in the United States, one State alone, Indiana, boing represented by 37,902 cases. Tho chief centre of smallpox infection in the United States recently has been in the north-west corner of the country which comprises the States of Montana, Washington, Idaho and Oregon, while the lowest incidence is in the New England and Middle Atlantic States, followed by the States in the south-east corner of the country. The high incidence in Indiana is to be attributed to the fact that at a recent survey less than 13 per cent of the Indiana pre-school children and not more than 53 per cent of school children less than ten years of age were found to be vaccinated. It is therefore highly desirable that the following warnings should be widely spread: (1) no one is naturally immune to smallpox ; (2) protection against it must be acquired artificially by vaccination; (3) the immunity conferred by vaccination is not life long, but must be renewed by revaccination at intervals of seven years or when an outbreak of smallpox occurs.

\section{Recent Earthquakes}

ON August 24 an earthquake of considerable intensity caused destruction in places 50 miles apart in southern Peru. The epicentre of the shock was probably a little distance to the north-west of Acari, which is a town in the foothills of the Andes in the province of Arequipa. The town of Acari was almost destroyed and there are reported to be large numbers of dead and injured. At Nazca, a town some 50 miles north-west of Acari, one third of the buildings were completely destroyed and 80 per cent of the population are homeless. Here 20 people are reported to have been killed and several injured. At the coast near the port of Nazca the sea receded some 200 yards and then came back and flooded the port together with about $1,000 \mathrm{yd}$. of the Pan-American coastal highway. The shock was well recorded at Stonyhurst College Observatory, near Blackburn ; the Rev. J. P. Rowland, S.J., reads $e P_{E}$ at 23h. 03m. 37s. U.T. on August 24, the maximum ground amplitude at Stonyhurst being $600 \mu$ at $39 \mathrm{~m}$. 40s. U.T. The shock finished recording at 04h. 10m. U.T. on August 25, all the interpretations being tentative.

The seismograph at Stonyhurst also recorded another earthquake, this time on August 27 at 06h. 18m. 40s. U.T. The record was well defined, but the amplitudes were much smaller than those of the Peruvian shock, and the epicentral distance from Stonyhurst much less. The German radio has reported an earthquake in Albania. In one village 80 per cent of the buildings are said to be uninhabitable, and many people killed and injured.

\section{Announcements}

SIR JoHN OrR, director of the Rowett Research Institute, Aberdeen, has been appointed professor of agriculture in the University of Aberdeen. He will retain the directorship of the Institute.

THE Minister of Agriculture and Fisheries has appointed Mr. F. A. Secrett to be honorary adviser on vegetable production. Mr. Secrett is the head of Messrs. F. A. Secrett and Co., the well-known firm of vegetable growers. His wide experience and intimate knowledge of the industry will be invaluable to the Ministry in the work of increasing the production of home-grown vegetables.

Tirw next meeting of the Parliamentary and Scientific Committee to be hold in Room 6 of the House of Commons, at 2.45 p.m. on September 8 , will consider, among other things: "further action to be taken on the Motion now on the Order Papers of the House with a view to the setting up of a central Technical and Scientific Board; to consider representations from a representative from the Geological Society with regard to the better use of geology in conn exion with the war effort."

Following the conference held at the Institution of Civil Engineers on August 25 to discuss generally the question of civil engineering and the building industry, discussion meetings will be held at four weekly intervals beginning September 15 at 2.30 p.m., to consider the specific problems that emerge. $\mathrm{Mr}$. George Hicks, Parliamentary Secretary to the Ministry of Works and Planning, will be the principal speaker at the first meeting. Particulars and tickets for a particular meeting or for the series may be obtained on application to the secretary of the Institution of Civil Engineers, Creat George Stroet, Westminster. 